\title{
Production of Tannase by Aspergillus tamarii in Submerged Cultures
}

\author{
Andréa M. Costa ${ }^{1}$, Wanessa X. Ribeiro ${ }^{1}$, Elaine Kato ${ }^{1}$, Antonio Roberto G. Monteiro ${ }^{2}$ and \\ Rosane Marina Peralta ${ }^{1}$ * \\ ${ }^{I}$ Departamento de Bioquímica; Universidade Estadual de Maringá; 87020-900; rmperalta@uem.br; Maringá - PR \\ - Brasil. ${ }^{2}$ ESUMAR; Maringá - PR - Brasil
}

\begin{abstract}
The production of tannase by Aspergillus tamarii was studied in submerged cultures. The fungus produced an extracellular tannase after two days of growth in mineral medium containing tannic acid, gallic acid and methyl gallate as carbon source. The best result was obtained using gallic acid as inducer (20.6 U/ml). The production of enzyme was strongly repressed by the presence of glucose. Crude enzyme was optimally active at pH 5.0 and $30^{\circ} \mathrm{C}$. The enzyme was stable in a large range of $\mathrm{pH}$ and up to the temperature of $45^{\circ} \mathrm{C}$.
\end{abstract}

Key words: Aspergillus tamarii, enzyme, fungal biomass, submerged cultures, tannase, tannins

\section{INTRODUCTION}

Tannin acyl hydrolase (EC 3.1.1.20), commonly called tannase, catalyzes the hydrolysis of ester bonds in hydrolysable tannins such as tannic acid, thereby releasing glucose and gallic acid (Bhat et al., 1998, Lekha and Lonsane, 1997). Tannins are defined as naturally occurring water-soluble polyphenols of varying molecular weight depending on the bonds possessed with proteins and polysaccharides (cellulose and pectin). Tannins are widespread in the plant kingdom, are found in the leaves, fruits, bark and wood. They occur in many edible fruits and vegetables and are often considered nutritionally undesirable because they form complexes with protein, starch and digestive enzymes and cause a reduction in nutritional value of food (Chung et al., 1998).

Tannase finds widespread application in the food and beverage processing. At the moment, most of the commercial applications of tannase are in the manufacturing of instant tea, where it is used to eliminate the water insoluble precipitates, wine, beer and coffee-flavored soft drinks (Aguilar and Sanches, 2001). Other important application of tannase in the food industry is its use as substrate for the chemical synthesis of pyrogallol or ester gallates, which are used as preservatives (Sharma and Gupta, 2003, Kar and Banerjee, 2000). Gallic acid is also used in the enzymatic synthesis of propyl gallate, which is mainly used as antioxidant in fats and oils, as well as in beverages (Banerjee et al., 2005).

Although tannase is present in the plants, animals and microorganisms, it is mainly produced by the microorganisms (Ayed and Hamdi, 2002, Belmares et al., 2004). The filamentous fungi of the Aspergillus genus have been widely used for tannase production (Bajpai and Patil, 1996, Banerjee et al., 2001, Pinto et al., 2001). The production of tannase by Aspergillus sp can occur in the absence of tannic acid, but these fungi

\footnotetext{
${ }^{*}$ Author for correspondence
} 
tolerate tannic acid concentrations as high as $20 \%$ without having a deleterious effect on both the growth and enzyme production. Studies on tannase production by Aspergillus sp can be done by various methods such as the liquid surface, submerged, modified solid-state cultures and solid state cultures (Bradoo et al., 1997, Belmares et al., 2004). The use of the submerged culture is advantageous because of the ease of sterilization, and process control is easier to engineer in these systems. Depending on the strain and the culture conditions, the enzyme can be constitutive or inducible, showing different production patterns. Phenolic compounds such as gallic acid, pyrogallol, methyl gallate and tannic acid are normally considered as tannase inducers, although repression in the production of tannase by gallic acid has also been described (Bradoo et al., 1997). Based on a preliminary screening of various soil isolates and other available fungal cultures, one of these organisms, Aspergillus tamarii, was selected for further studies. Therefore, the purpose of this work was to study the production of tannase by $A$ tamarii in submerged cultures as well as the effect of $\mathrm{pH}$ and temperature on the enzyme activity and stability.

\section{MATERIALS AND METHODS}

\section{Microorganism and maintenance of culture}

The strain of Aspergillus tamarii used in this study was isolated from the soil during a screening program for hydrolytic enzyme-producing microorganisms (Kadowaki et al., 1997, Souza et al. 1997). It was deposited in the Fundação Tropical de Pesquisas e Tecnologia André Tosello Collection, Campinas, Brazil. In the lab, it was routinely maintained on potato dextrose agar at $4^{\circ}$ C.

\section{Preparation of spore inoculum.}

The fungal spore inoculum was prepared by adding $2.5 \mathrm{ml}$ of the sterile distilled water containing Tween 80 to a fully sporulated culture. The spores were dislodged using a sterile inoculation loop under the strict aseptic conditions and the number of viable spores in the suspension was determined using the plate count method. The volume of $1 \mathrm{ml}$ of spore suspension was used as the inoculum, with concentration of 5 $\mathrm{x} 10^{9}$ spores.
Production of extracellular tannase in submerged cultures

The spore suspension was inoculated in $125 \mathrm{ml}$ Erlenmeyer flasks containing $25 \mathrm{ml}$ of sterilized mineral medium containing per liter: $\mathrm{KH}_{2} \mathrm{PO}_{4} 1.0$ $\mathrm{g} ; \mathrm{MgSO}_{4} .7 \mathrm{H}_{2} \mathrm{O} 2.0 \mathrm{~g}, \mathrm{CaCl}_{2}, 1.0 \mathrm{~g} ; \mathrm{NH}_{4} \mathrm{Cl}, 3.0 \mathrm{~g}$; yeast extract, $1 \mathrm{~g}$. Filter-sterilized tannic acid, methyl gallate, gallic acid at $1 \%$ concentration was added to the autoclavated medium. Different additional carbon source were added separately to the above-mentioned medium for studying their effect on the enzyme production. The cultures were grown for up six days at $140 \mathrm{rpm}$ in an incubator shaker at $28^{\circ} \mathrm{C}$. The samples were withdrawn at regular intervals of one day. The biomass were separated by the filtration through Whatman $\mathrm{n}^{0} 1$ filter paper. The cell-free culture broth was assayed for the extracellular tannase activity. The mycelium was washed three times with water. To determine the dry weight of the mycelium (biomass production), it was dried overnight at $60^{\circ} \mathrm{C}$.

\section{Enzyme assay}

Tannase activity was estimated by the method of rhodanine (Sharma et al., 2000). The method is based on the formation of a chromogen between gallic acid (released by the action of tannase on methyl gallate) and rhodanine (2 thio-4ketothiazolidine). The pink color developed was read at $520 \mathrm{~nm}$ using a spectrophotometer (Shimadzu UV-160A, Japan). Tannase activity was expressed in international units. One unit of tannase activity was defined as the amount of enzyme required to liberate one micromole of gallic acid per minute under the defined reaction conditions.

\section{Enzyme precipitation}

The enzyme from the clear gallic acid culture filtrate was precipitated by the drop-wise addition of cooled acetone at $4^{\circ} \mathrm{C}$ to a saturation level of $75 \%(\mathrm{v} / \mathrm{v})$. After $1 \mathrm{~h}$ contact time, the precipitate was removed by centrifugation at 5,000 $\mathrm{rpm}\left(4^{\circ} \mathrm{C}\right)$ for $30 \mathrm{~min}$, freed of acetone by vacuum drying and dissolved in a minimal amount of the distilled water. The acetone-precipitated enzyme was used in the following experiments. 


\section{Effect of pH and temperature on the activity and stability of tannase}

The optimum $\mathrm{pH}$ was determined using the substrate in McIlvaine's buffer ( $\mathrm{pH} 3.5$ to 8.5). The stability of the crude enzyme was examined at different $\mathrm{pH}$ by incubating the enzyme with the buffers of different $\mathrm{pH}$ ranging from 3.5 to 8.5 for $24 \mathrm{~h}$. The residual activity was estimated after incubation under the standard assay conditions and expressed as the percentage of the initial activity. For the determination of the temperature optimum, the enzyme assays were carried out at temperature ranging from 25 to $70^{\circ} \mathrm{C}$. The thermal stability was investigated by incubating the enzyme at 30 , 40,50 and $60^{\circ} \mathrm{C}$ for $2 \mathrm{~h}$. Immediately afterwards the reaction mixtures were immersed in an ice bath and then the residual activities were tested under standard conditions and it is expressed as the percentage of the initial activity.

\section{Chemicals}

The enzymatic substrates and carbon sources were obtained from Sigma Chemical Corp. (St. Louis, Mo). All other reagents were of analytical grade.

\section{RESULTS AND DISCUSSION}

The ability of A. tamarii to grow and to produce tannase on different carbon sources was studied (Fig. 1). Tannase activity and biomass were determined in the early stationary growth phase. Among the carbon source assayed, good growth was obtained with glucose, starch, xylan and sucrose, but the highest tannase activities were observed when the organism was grown on gallic acid $(13.1 \mathrm{U} / \mathrm{ml})$, which was followed by methyl gallate $(9.7 \mathrm{U} / \mathrm{ml})$ and tannic acid $(9.3 \mathrm{U} / \mathrm{ml})$. These results showed the potential of $A$. tamarii as a tannase producer. In a recent work where Aspergillus sp and Penicillium sp were screened to produce tannase, the highest levels of the activities produced by $A$. fumigatus and $A$. versicolor in submerged cultures with tannic acid as substrate were 8.3 and $7.0 \mathrm{U} / \mathrm{ml}$, respectively (Batra and Saxena, 2005).

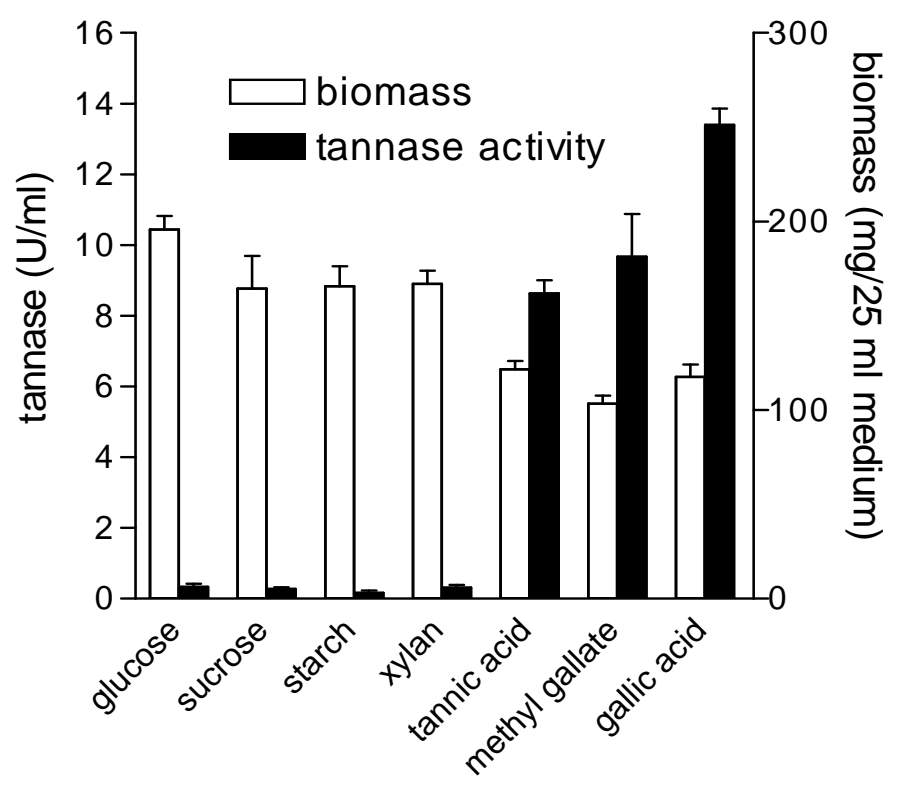

Figure 1 - Production of extracellular tannase and biomass by A. tamarii in submerged cultures. The cultures were developed for 4 days at $140 \mathrm{rpm}$ and $28^{\circ} \mathrm{C}$. Values are the mean $\pm \mathrm{SD}$ of triplicate cultures

A typical time course of the extracellular tannase production by $A$. tamarii in submerged cultures is shown in Fig. 2A. Optimum enzyme production occurred after two days of cultivation, though the 
maximum growth was not attained until four days. The cultures where gallic acid was used as the substrate produced the highest tannase level (20.6 $\mathrm{U} / \mathrm{ml}$ ). High levels of tannase activity were also obtained in the cultures with tannic acid and methyl gallate (12.4 and $10.1 \mathrm{U} / \mathrm{ml}$, respectively). Phenolic compounds such as gallic acid, pyrogallol, methyl gallate and tannic acid have been described as tannase inducers (Bajpai and Patil, 1997). However, the induction mechanism has not been demonstrated and there is some controversy about the role of some of the hydrolysable tannins constituents on the synthesis of tannase (Belmares et al., 2004). For example, the addition of gallic acid in the submerged cultures of A. niger Aa-20 (Aguilar et al., 2001) and A. japonicus (Bradoo et al., 1997) repressed the production of tannase.
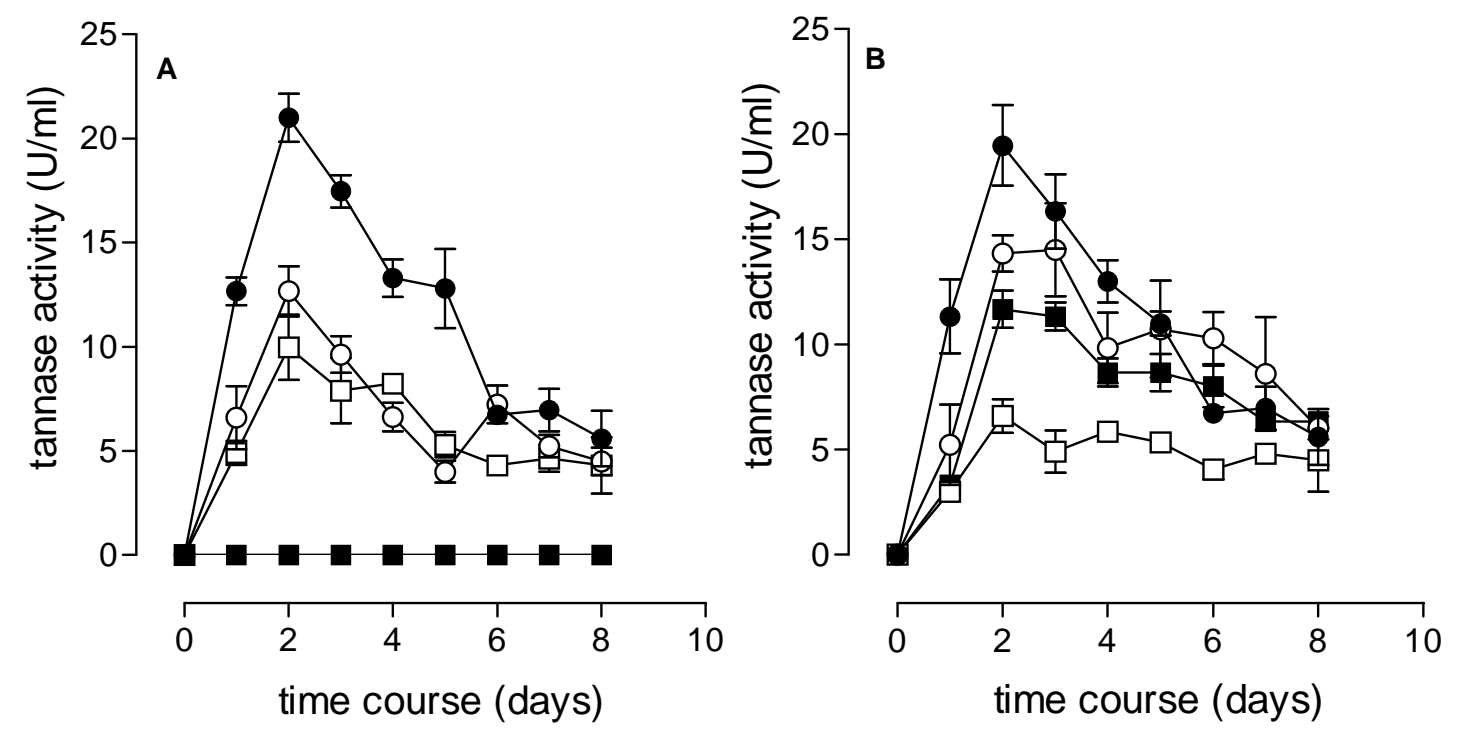

Figure 2 - Time course of extracellular tannase production by A. tamarii in submerged cultures. In A: The following carbon sources at $1.0 \%(\mathrm{w} / \mathrm{v})$ were used: starch, glucose or sucrose $(\square)$, tannic acid (०), gallic acid ( $\square)$, and methyl gallate $(\bullet)$. In B: The cultures were developed using $1.0 \%$ gallic acid as substrate in association with different amounts of glucose. Without glucose $(\bullet)$; plus glucose $0.2 \%(0)$; plus glucose $0.5 \%$ ( $)$; plus glucose $1.0 \%(\square)$.Values are the mean \pm SD of triplicate cultures

Tannase repression experiments were carried out using gallic acid as inducer and several glucose concentrations as a potential repressor (Fig. 2B). Even the addition of small amounts of glucose $(0.2 \%)$ caused a decrease in the level of tannase. The addition of higher amounts of glucose $(1.0 \%)$ drastically reduced the production of the enzyme. It has been reported that the synthesis of tannase is not under catabolic repression in the presence of glucose or sucrose (Aguilar and Sanches, 2001). In fact, the addition of carbon sources such as glucose, fructose, sucrose, maltose and arabinose to the culture medium at initial concentrations from 10 to $30 \mathrm{~g} / \mathrm{l}$ improved the production of tannase by A. niger (Belmares et al., 2004). The addition of glucose in the submerged cultures of $A$. japonicus using tannic acid as substrate, did not decreased the production of tannase (Bradoo and Gupta, 1997). On the other hand, the addition of $2.0 \%$ glucose in the submerged cultures of Aspergillus niger Aa-20, resulted in strong catabolite repression (Aguilar et al., 2001).

Some properties of A. tamarii extracellular tannase were studied. The enzyme was precipitated with cold acetone with more than $70 \%$ of recovery. The acetone-precipitated tannase was active at the acidic $\mathrm{pH}$ and the activity decreased as the $\mathrm{pH}$ approached the alkaline range. The optimum activity was recorded at $\mathrm{pH} 5.0$ (Fig. 3A), but substantial activities were detected at $\mathrm{pH}$ values ranging 
from 4.0 to 8.0 , which could be a positive aspect regarding its use in the brewing industry. At $30^{\circ}$ $\mathrm{C}$, the enzyme was totally stable between $\mathrm{pH} 3.0$ and 8.0 for $2 \mathrm{~h}$ (Fig 3A). Fungal tannases are acidic enzymes in general. There are reports describing the optimum $\mathrm{pH}$ as 5.0 in case of tannase from A. awamori (Mahapatra et al., 2005), pH 5.5 in case of tannase from A. flavus and A. oryzae (Batra and Saxena, 2005) and $\mathrm{pH}$

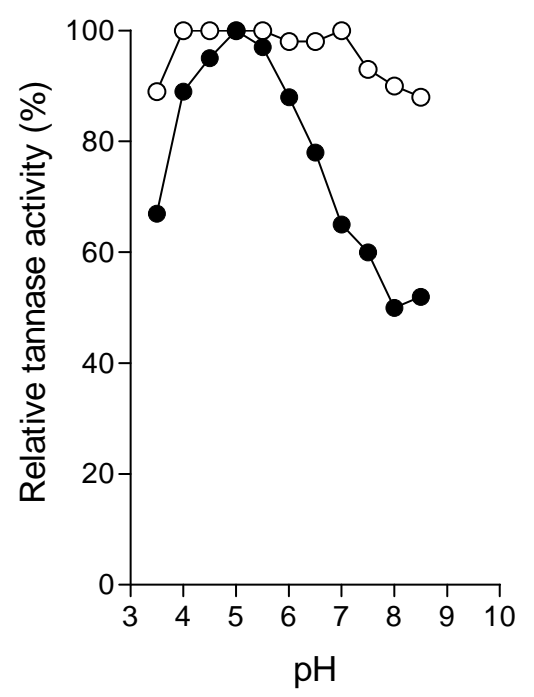

6.0 in case of tannase from A. niger (Sabu et al., 2005). The enzyme was optimally active between $30-35^{\circ} \mathrm{C}$ (Fig 3B). Similar observations were related for tannase from several Aspergillus sp (Mahapatra et al., 2005). The enzyme was stable at $40^{\circ} \mathrm{C}$ for more than $2 \mathrm{~h}$, but it was not stable at temperature higher than $45^{\circ} \mathrm{C}$ (Fig 3B).

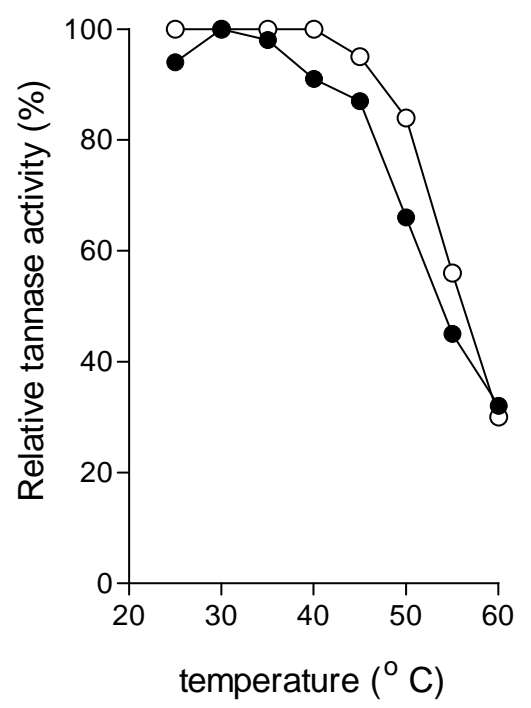

Figure 3 - Effect of $\mathrm{pH}(\mathrm{A})$ and temperature (B) on tannase activity $(\bullet)$ and stability (०). The stability of the crude enzyme was examined at different $\mathrm{pH}$ by incubating the enzyme with the buffers of different $\mathrm{pH}$ ranging from 3.5 to 8.5 for $24 \mathrm{~h}$. For the determination of the temperature optimum, the enzyme assays were carried out at temperature ranging from 25 to $70^{\circ} \mathrm{C}$. The thermal stability was investigated by incubating the enzyme at $30,40,50$ and $60^{\circ} \mathrm{C}$ for $2 \mathrm{~h}$

\section{CONCLUSION}

This is the first report of tannase production by A. tamarii. From the above results it is evident that this fungus could be a potential tannase producer. The strain was able to produce tannase in the medium containing tannic acid as the sole carbon source. However, gallic acid was the best inducer for tannase activity. One advantage of the use of this fungus to produce tannase is that it can be produce the maximum enzyme within a short period of cultivation. Thus, its production at higher levels should be attempted.

\section{ACKNOWLEDGMENTS}

This work was supported by the Conselho Nacional de Desenvolvimento Científico e Tecnológico $(\mathrm{CNPq})$, Fundação Araucária and Universidade Estadual de Maringá. The authors are grateful to M.A.F. Costa and A. Chaves for their technical assistance.

\section{RESUMO}

A produção de tanase por um novo potencial produtor, o fungo filamentoso Aspergillus tamarii, foi parcialmente caracterizada neste estudo. $\mathrm{O}$ fungo produziu uma tanase 
extracelular em culturas submersas após 2 dias de crescimento em meio mineral contendo ácido tânico, ácido gálico ou metil galato como fonts de carbono. Os melhores resultados foram obtidos em culturas com ácido gálico (20,6 $\mathrm{U} / \mathrm{ml}$ ). A produção da enzima foi fortemente inibida por glicose. A enzima bruta foi otimamente ativa em $\mathrm{pH} 5,0$ e a $30^{\circ} \mathrm{C}$ e estável em ampla faixa de $\mathrm{pH}$ e em temperaturas inferiores a $45^{\circ} \mathrm{C}$.

\section{REFERENCES}

Aguilar, C.N.; Augur, C.; Favela-Torres, E. and Viniegra-González G. (2001), Induction and repression patterns of fungal tannase in solid-state and submerged cultures. Proc Biochem., 36, 565570.

Aguilar, C.N. and Sanches, G. (2001), Review: sources, properties, applications and potential use of tannin acyl hydrolase. Food Sci Technol. Int., 7 , 373-382.

Ayed,L.; Hamdi, M. (2002), Culture conditions of tannase production by Lactobacillus plantarum. Biotechnol. Let., 24, 1763-1765.

Bajpai, B. and Patil S. (1997), Induction of tannin acyl hydrolase (EC 3.1.1.20) activity in some members of fungi imperfecti. Enz Microb Technol., 20, 612 - 614 .

Bajpai, B. and Patil S. (1996), Tannin acyl hydrolase (EC 3.1.1.20) activity of Aspergillus, Penicillium, Fusarium and Trichoderma. World J. Microbiol. Biotechnol., 12, 217-220.

Banerjee, R.; Mondal, K.C. and Pati, B.R. (2001), Production and characterization of extracellular and intracellular tannase from newly isolated Aspergillus aculeatus DBF 9. J. Bas. Microbiol., 41, 313-318.

Banerjee, R.; Mukherjee, G. and Patra, K.C. (2005), Microbial transformation of tannin-rich substrate to gallic acid through co-culture method. Biores. Technol., 96, 949-953.

Batra, A. and Saxena, R.K. (2005), Potential tannase producers from the genera Aspergillus and Penicillium. Proc. Biochem., 40, 1553-1557.

Belmares, R.; Contreras-Esquivel, J.C.; RodriguezHerrera, R.; Coronel, A.R. and Aguilar, C.N. (2004), Microbial production of tannase: an enzyme with potential use in food industry. Lebensm-Wiss U-Techno, 37, 857-864.
Bhat, T.K.; Singh,, B. and Sharma, O.P. (1998), Microbial degradation of tannins-a current perspective. Biodegradation, 9, 343-357.

Boadi, D.K. and Neufeld, R.J. (2001), Encapsulation of tannase for the hydrolysis of tea tannins. Enz. Microb. Technol., 28,590-595.

Bradoo, S.; Gupta, R. and Saxena, R.K. (1997), Parametric optimization and biochemical regulation of extracellular tannase from Aspergillus japonicus. Proc. Biochem. 32,135-139.

Chung, K.T.; Wong, T.Y.; Wei, C.I.; Huang, Y.W. and Lin, Y. (1998), Tannins and human health: a review. CRC Crit. Rev. Food Sci. Nutr., 38, 42414264 .

Kadowaki, M.K.; Souza, C.G.M.; Simão, R.C.G. and Peralta, R.M. 1997, Xylanase production by Aspergillus tamarii. Appl. Biochem. Biotechnol., 66, 97-106.

Kar, B.; Banerjee, R. and Bhattacharyya, B.C. (2000), Modeling gallic acid production rate by empirical and statistical analysis. Braz. Arch. Biol. Technol., 43, 509-513.

Lekha, P.K. and Lonsane, B.K. (1997), Production and application of tannin acyl hydrolase: state of art. Adv. Appl. Microbiol., 44, 215-260.

Mahapatra, K.; Nanda, R.K., Bag, S.S.; Banerjee, R.; Pandey, A. and Szakacs, G. (2005) Purification, characterization and some studies on secondary structure of tannase from Aspergillus awamori Nakazawa. Proc. Biochem., 40, 3251-3254.

Pinto, G.A.S.; Leite, S.G.F.; Terzi, S.C. and Couri, S. (2001), Selection of tannase-producing Aspergillus strains. Braz. J. Microbiol., 32, 24-24.

Sabu, A.; Kiran, G. and Pandey, A. (2005), Purification and characterization of tannin acyl hydrolase from Aspergillus niger ATCC 16620. Food Technol. Biotechnol., 43, 133-138.

Sharma, S.; Bhat, T.K. and Dawra, R.K. (2000), A spectrophotometric method for assay of tannase using rhodanine. Anal. Biochem., 279, 85-89.

Sharma, S. and Gupta, M.N. (2003), Synthesis of antioxidant propyl gallate using tannase from Aspergilus niger van Teighem in nonaqueous media. Bioorganic and Medicinal Chemistry Letters, 13, 395-397.

Souza, C.G.M.; Simão, R.C. and Peralta, R.M. (1997), Effect of $\mathrm{pH}$ on the production, activity and stability of xylanases by Aspergillus tamarii. Braz. Arch. Biol. Technol., 44, 809-815. 